\title{
Opinion note
}

\section{What will happen with the name Acacia Mill.?}

\section{¿Qué pasará con el nombre Acacia Mill.?}

\author{
Lourdes Rico-Arce \\ Royal Botanic Gardens Kew, Richmond, Surrey, TW9 $3 A B$ \\ *Correspondent: L.Rico@kew.org
}

1) The voting that took place at the nomenclatural session of the International Botanical Congress (IBC) in Vienna was illegal from the point of view of parliamentarian procedure and practical application.

2) Only one species type must be assigned to the genus Acacia; this would be decided through a new procedure that follows the established rules.

3) Taxonomically speaking, the former subgenera of the genus Acacia belong to at least three different lineages that resolve within the tribe Mimoseae; therefore, the current debate for assigning a type to the genus revolves around two of the three subgenera: Acacia (Acacia) and Acacia (Phyllodineae $=$ Racosperma $)$.

At the IBC in Vienna (2005), the "decision" to conserve the name Acacia with a new type from Australia (Acacia penninervis) was taken, replacing the original African type (Acacia nilotica). This effectively restricts the name of Acacia to the group of largely Australian "wattles", excluding its use for the widespread tropical true acacias (outside Australia with the exception of seven native species).

The name Acacia is well used beyond the scope of the scientific community, and this implies numerous problems, the current retypification is provisional; to be effective, it must be ratified in the next nomenclatural session concurrently with the ratification of the International Botanical Nomenclature Code of Vienna 2005, in Melbourne (2011), when there will be a VETO to avoid the ratification of the illegal retypification. If you do not agree with this retypification, currently there is a contingent that will aim to VETO this retypification; at the same time, additional support from the International community is sought (www.acaciavote.com).

Recibido: 10 diciembre 2010; aceptado: 09 febrero 2011
Why?

The events that took place during the voting procedure in Vienna have been described clearly by several authors (Rijckevorsel, 2004, 2006; Moore 2008, Moore et al. 2010, www.acaciavote.com). Independently that the majority of votes $(54.9 \%)$ were against the change that took place in Vienna, the confusion was caused by the mixing up of issues pertaining to the rules of how plants are named and the taxonomic issues. The debate, therefore, about which divisions of Acacia are recognized at what taxonomic level was quite independent from the central issue treated in Vienna, the discussion of why the acacia type passed to the wattles, was only because the latter group comprises a larger number of species. The retypification initiative took little heed of the many other factors involved, i.e. social, cultural, ecological, economic, demographic or historical concerns, that needed to be debated prior to a vote for or against the retypification. It is well known that now a legal decision of the Acacia typification is not going to satisfy both groups (acacia and wattles) and probably there will be someone submitting a proposal that will go beyond the commonly accepted situations "following" the nomenclatural rules and the re-typification process.

Miller and Bayer (2001), Luckow et al. (2003), and more recently Gómez-Acevedo et al. (2010) and Bouchenak-Khelladi et al. (2010) have provided more elements supporting these divisions based on morphology, molecular evidence (nuclear and chloroplast) and diversification rates. Genus Acacia with subgenera was used in Rico-Arce (2007) for the benefit of the users, allowing them to have all possible names with their alternative equivalents. Since then, there was already categorical evidence that the genus was divided and that several genera have to be recognized or reinstated. In my subsequent publications, at least Senegalia Raf. and Acaciella Britton \& Rose are recognized, but it is not the case for Vachellia Wight \& Arnott and Racosperma Mart. 
My main objective is to make the reader aware of the illegality of the procedure that took place in Vienna at the nomenclature session (2005); if there is a type for the genus Acacia, this type needs to be established following a proper process, with the implication that the genus Acacia should have only one type species; in addition, according to the current scientific evidence, Acacia s.l. (with three subgenera) does not exist. What the name users will follow?

\section{Literature cited}

Bouchenak-Khelladi, Y., O. Maurin, J. Hurter and M. van der Bank. 2010. The Evolutionary history and Biogeography of Mimosoideae (Leguminosae): An Emphasis on African acacias. Molecular Phylogenetics and Evolution 57:495-508.

Gómez-Acevedo, S., L. Rico Arce, A. Delgado Salinas, S. Magallón and L. E. Eguiarte. 2010. Neotropical mutualism between Acacia and Pseudomyrmex: Phylogeny and divergence times. Molecular Phylogenetics and Evolution 56:393-408.

Luckow, M., J. T. Miller, D. J. Murphy and T. Livshultz.
2003. A phylogenetic analysis of the Mimosoideae (Leguminosae) based on chloroplast DNA sequence data. In Advances in Legumes Systematics, B. B. Klitgaard y A. Bruneau (eds.). Royal Botanic Gardens, Kew, London. p. 197-220.

Miller, J. M. and R. J. Bayer. 2001. Molecular phylogenetics of Acacia (Fabaceae: Mimosoideae) based on the chloroplast matK coding sequence and flanking trnK intron spacer regions. American Journal of Botany 88:697-705.

Moore, G. 2008. Action on the proposal to conserve the name Acacia at the Nomenclature Section of the XVII International Botanical Congress in Vienna: Did the ayes have it? Linnean 24, 2:16-120.

More, G. et al. (68 more authors). 2010. Acacia, the 2011 Nomenclature Section in Melbourne, and beyond. Taxon 59:1188-1195.

Rico Arce, M. de L. 2007. A Checklist and Synopsis of American Species of Acacia (Leguminosae: Mimosoideae). CONABIO, México, D.F. 207 p.

Rijckevorsel, P. van. 2006. Acacia: What did happen at Vienna? Anales del Jardín Botánico de Madrid 63:107-110.

Rijckevorsel, P. Van. 2004. Duizend Acacia-soorten gered. Bionieuws 14, 17: 4. 